\title{
Exploring Perceptions of Online Readers of Newsday And The Herald on Media Representations of War Veterans In Zimbabwe's Politics In The Year 2016.
}

\author{
By Peter Chiridza ${ }^{1}$, Karen Linde $^{2}, \&$ Elliot Muchena ${ }^{3}$ \\ ${ }^{1}$ Lecturer, Department of Journalism and Media Studies; Zimbabwe Open University, Mashonaland West \\ Region, Chinhoyi, Zimbabwe. \\ ${ }^{2}$ Student, Department of Media and Society Studies, Midlands State University, Gweru, Zimbabwe. \\ ${ }^{3}$ Lecturer, Department of Media and Journalism Studies, Zimbabwe Open University, Harare Region, Harare.
}

\begin{abstract}
This study explores the perceptions of online audiences of Newsday and The Herald on the coverage of war veterans by these two papers in 2016. The study seeks to identify the reasons that influence audiences to have varied perceptions on the coverage of war veterans by these two daily Zimbabwean papers in 2016. The research also shows how online news commentary sections are an alternative platform for audience engagement with themselves and with the media houses that publish newspapers. The research made use of theories like the digital public sphere and the encoding and decoding model to better understand the phenomenon of online audiences. Archival research was employed by the researchers to obtain data, which was thematically presented. The research findings confirm that audiences hold varied perceptions on the coverage on war veterans in 2016. The perceptions varied from those that viewed the coverage as credible, hostile and some that viewed the coverage as tainted by subjected views and vested interests of the publishers. The findings also reflect that the commentary section works as a new form of a public sphere, where people engage in debates on topical issues that the media represent to them.
\end{abstract}

\section{INTRODUCTION}

This study explores the perceptions of online audiences of Newsday and The Herald on the coverage of war veterans by these two papers in 2016. The study also explores the reasons that prompt readers to have varying perceptions and it unpacks online news as an alternative platform for audience engagement with themselves and the media. The Newsday is a subsidiary of the privately-owned company Alpha Media Holding $(\mathrm{AMH})$. It is a daily newspaper which runs in print and online. The organisation pledges to its readers that it seeks the truth and offers relevant contexts and analyses. The Herald is a government owned daily newspaper published in Harare. The government bought The Herald and other papers from The Argus group in 1981 soon after independence and established the Zimbabwe Mass Media Trust (ZMMT) to operate them. Its online commentary section makes it ideal for the study as it is very vibrant and allows readers to engage with other readers and the paper's content passing judgements on the political issues that the paper covers.

This study is going to focus on comments made by the readers of these two papers after reading stories that covered or talked about Zimbabwe's war veterans in the year 2016. The term war veterans refers to former armed militants that fought the bush war against colonial Rhodesia's government from around 1966 to 1979. Today these war veterans are recognised under their association known as the Zimbabwe National Liberation War Veterans Association (ZNLWVA) which is an organisation consisting of former combatants of the Zimbabwe African National Liberation Army (ZANLA) and Zimbabwe People's Revolutionary Army (ZIPRA) who fought under ZANU and ZAPU respectively. ZNLWVA was mainly formed to look into the needs of demobilised combatants. This association has championed the welfare needs of war veterans since its formation and sometimes it has also been involved in political activities like campaigning for the ruling ZANU PF party. When one takes a closer look at the history of the association, it can be observed that it has been an association of disgruntlement. Musemwa (1995) notes that the problem of violence, anarchy and lawlessness that some Zimbabwe associated with war veterans from 1997 can be attributed to the failure by the government to implement a sound sustainable policy of demobilisation catering for the welfare of the former fighters and facilitating their reintegration into society, meaning to say war veterans had dissatisfactions which led them to have active participation in the political issues of the country. In the year 2016 war veterans became a constant feature in the media in Zimbabwe. Here the agenda setting framework of the media would suggest that the media were specifically framing their messages and deliberately or inadvertently conditioning Zimbabweans to think about war veterans. Shen (2004) states that "...media frames can have significant consequences on how audiences perceive and understand issues and can alter public opinions on ambivalent and controversial issues". What is quite clear in all this framing is that this war veterans were very important and powerful persons to 
Exploring perceptions of online readers of Newsday and The Herald on media representations of ..

warrant such attention from the media. Happer and Philo (2013) note that, "The information that people are given in media accounts can both legitimise the actions of the powerful, and facilitate change at the collective level, but can also limit and shape the behaviours of individuals........The media are in essence a contested space in which the most powerful groups can establish the dominance of specific messages [although] the complexity of the reception process then creates the possibility of variations in attitudinal and behavioural response". What this entails is that there is a way in which the coverage of war veterans by the media impacted/affected the audiences to shape public opinion; but this impact is hard to pinpoint because of the contested nature of the effects of media messages. This study will therefore explore the online comments of readers who read the stories on war veterans to establish if a pattern can be noticed on what public opinion is like concerning war veterans in Zimbabwe.

\section{LITERATURE REVIEW AND THEORETICAL FRAMEWORK}

The online commentary section is a new feature that came along with the advent of the new media. According to Olson and Almgren (2015) new commentary feature is an emerging public sphere. Therefore, it gives opportunity to citizens to engage in discussion. Hung and Yoo (2008) note that the interactive feature allows for audiences' active engagement in communication process. Online audiences are anonymous and this encourages wider participation on issues that will be under discussion or debate as they have no fear to express their opinions. Cress (2005) asserts that members of groups in which people are anonymous exchange more information. Olson and Almgren (2015) assert that anonymity shapes and stirs the online discussion, it has offered great potential to the audience and media relationships rather than letters to the editor and it offers participatory potential. In this scenario the advent of new technology has proved to have made a transformation in the audiences from a passive audience to a fairly active one. Indeed, the development of such features has the potential to trigger a paradigm shift in mass media by challenging the traditional unidirectional flow of messages (Chung, 2007: 43). In this essence the online commentary sections empower citizen's overs news content as they are enabled with the platform to pass their judgements on the coverages, thus audiences have a degree of control over the media. Dahleberg (2001) notes that the online commentary section is a virtual sphere that enhances discussion and is democratised. There is a multi-directional flow of information as audiences now have direct influence in the production of media content. Therefore this implies that the digital sphere emerged as a liberator to the audiences, hence its relevance to the study as the research seeks to understand how audiences have been empowered with active participation through the responses they make on Newsday and The Herald online commentary sections.

The media has changed to an interactive one as audiences let out the different types of selfrepresentation through the various opinions and views they pass. This is further explained by (Slatcheva Petkova 2015) who note that the new technology of commentary feature is a platform that allows for the individuals to come together to share and consider information. Therefore, online media has a social impact in the various societies, hence the relevance of the study as it seeks to understand the different online readings towards the coverage of war veterans by Newsday and The Herald in 2016. This online commentary section has become possible today especially in the context of a world where the internet has taken centre stage. The discovery of the internet has changed the world and revolutionized how information is stored, published, searched for and consumed (Viner, 2013). The internet has impacted heavily on businesses, industries and has also crossed over into politics, medicine and the news media. The internet breaches geographical locations, cultural boundaries and ultimately, it affects people's day to day lives (Harper, 2010). Alejandro (2010:6) distinguishes between Web 1.0 and Web 2.0. In Web 1.0 model, a Web publisher uploads content to a Web site whilst in Web 2 content is created by the users of platforms and is characterized by 'open communication, decentralization of authority, freedom to share and re-use, and the idea of the market as a conversation'. The difference between social media and the erstwhile traditional broadcast and print media is summed up by Viner (2013) who notes that a newspaper is packaged as complete and sure of itself, whilst by contrast, digital news is constantly updated as an ongoing conversation with living, evolving, limitless and relentless qualities.

The public sphere theory will be used as a point of departure for this research. Bondebjerg (2015: 3) offers an exploration of the theoretical basis of political communication offered by Habermas (1989) who described the birth of a liberal model of a public sphere. The ideal form of this public sphere according to Habermas went into decline with the gradual development of a more and more commercialized media system; opinion building and reasoning in public was infiltrated not just by commercial interests but also by professional management, lobbying and manufacturing of ideas and politics (Bondebjerg, 2015: 3). Although Habermas was to later revise his overly pessimistic picture of the modern media in 2006, as noted by Bondebjerg (2015: 4), it is clear that this earlier description, to some extent is still relevant to the media in existence in today's age of consumerism. Boeder (2005) concurs to this by noting that the public sphere is alive and well today, although it will never be quite the same: 
Exploring perceptions of online readers of Newsday and The Herald on media representations of ..

Habermas' coffeehouse discourse has evolved in the direction of mediated communication within electronic networks: Its future is with the digital media, which offer exciting possibilities as digital networks enhance and change social structures. In a sense, the public sphere has always been virtual: Its meaning lies in its abstraction. Habermas' classical argument that the public sphere is intermittently threatened by — latent — power structures that attempt to inhibit and control the individual is undoubtedly correct. Yet at the same time, groups and individuals can indeed accomplish change by communicative action, and digital communications technology may empower them to do so (Boeder, 2005: NP).

The citation above shows that citizens can make use of digital platforms to accomplish a lot through communicative action. Although the cited passage does not refer to traditional journalism, it is relevant to this research because its assertion that the public sphere challenges latent powers that seeks to limit the freedoms of citizens augurs well with the objectives of this research, which seeks to participate in the creation of a healthy public sphere on the platform of online newspaper commentary section.

\section{METHODOLOGY}

The research is rooted in the qualitative approach. It is essentially a qualitative exploration and analysis, in the interpretive narrative model, of the varied perceptions of online readers of the two papers under study concerning the coverage of war veterans. A qualitative approach is appropriate here because it provides insights into the varied ways audiences respond and react to different coverages of similar events by different papers. Discourse analysis will be the research instrument in the study. Discourse analysis shall be used to examine the online comments made by readers of Newsday and The Herald. The supposition in doing discourse analysis is that language, written or spoken is as performative as it is functional. It should never be treated as a 'neutral, transparent, means of communication' (Berger 1991). The implication is that language is constructive and constitutive of social, political, economic life including historical aspects of life that exist in a particular community that capture beliefs, experiences and practices of those that use their respective languages.

\section{DATA PRESENTATION AND ANALYSIS}

The study established that audience interpretations of the coverage of war veterans was possibly influenced by their political affiliations. Although it was difficult to conclude this with certainty, the researchers were able to interpret the nature of comments as suggestive of the political preferences of the one making the comment. The researchers noted that acceptability or hostility of the audiences towards certain articles depended on whether the reporter would have written along the lines that favour their political affiliations. This is evident in the responses made by online audiences which clearly reflected that their line of argument was coloured by political underpinnings, for example if we consider one article published on 18 September 2016 which had the headline 'War vets still to pay second term fees'. A lot of comments after this Newsday article were hostile to the ruling ZANU PF party, with many comments castigating both the government and the war vets association. A lot of varied responses to the article of 25 July 2016 which had the headline 'War vets disown communique' have also been noted by the researchers. On this story, one reader raises questions on whether The Herald reporter had done the necessary investigative work before going to print as the story had a lot of loopholes. Another article in the Newsday had the title 'Government speaks on war vets'. Readers who commented on this articles gave varied opinions with some blasting the government for ill-treating the vets whilst some felt that the vets deserved the tear-gassing by the police as they were the same group that had propped the government for a very long time, and had watched the government use its heavy handed tactics against opposition figures.

Perceptions on war veterans thus varied from reader to reader but were largely influenced by the story that would have been read. The vets were in some instances viewed as greedy parasites who were bent on exacting benefits from the state and this was seen as stemming from a sense of entitlement after having fought the liberation war. Some readers dismissed war veterans as hypocritical crooks who fake that they ever fought the war in order to black mail the government to release funds for them. However not all perceptions on the vets were negative. Some readers regarded the vets as a group that has from time to time taken a leadership role in the political, economic and social affairs of Zimbabwe. Examples that are cited are that in their teens they waged war to liberate blacks, later they led in expropriating land from white farmers whilst today they have also found themselves getting involved in the politics of ZANU PF, a party which is now grappling with the succession of its leader Robert Mugabe who is now 93 years old.

One critical factor already mentioned which drives how readers perceive the subject matter of any article is the reportage slant of those who write and edit the stories in the Newsday and The Herald. The media in Zimbabwe are split into two camps, deliberately aligning themselves to their perceived champions of democracy and development. The Herald usually aligns itself with the ruling ZANU PF party whilst the Newsday supports those who oppose the ruling party. Because of such alignment, the media in Zimbabwe produces highly sensationalized articles. The media in Zimbabwe are the shrillest in cheering their chosen players in the political field, be it the ruling ZANU PF or other opposition parties and thus further fuelling the 
polarity, which in turn cascades down to online readers whose perception of issues reported upon is influenced by the reportage slants of respective newspapers.

Another important finding of this study is that the commentary sections of the two newspapers allowed audiences to give feedback to the newspapers as far as the quality of their reporting was concerned. This would, in a way enrich future coverage as the reporters who authored the stories would be able to check what facts were contested and what frames of news displeased the readers. Newsday and The Herald's audiences have been empowered to respond to various articles letting out various discourses and comments on their debates on the online commentary sections. There are a lot of advantages offered by a digital public sphere since online media enable more people to make their voices heard in society. Content can be posted rather easily online without the interference of gate-keeping processes and might empower those who have always wanted to engage in public debate but were previously marginalized by traditional media.

\section{CONCLUSION}

Online commentary sections that follow online newspaper articles are vibrant platforms where useful political debate occurs. War veterans in Zimbabwe are a powerful group that political actors in Zimbabwe cannot afford to ignore although they are also a group that largely divides the opinions of Zimbabweans with some seeing them as criminals and others lauding them as gallant sons and daughters of Zimbabwe who assume a leadership role on affairs that are problematic for the nation. Newspapers in Zimbabwe offer polarised views concerning political affairs of the nation and this polarisation cascades down to online readers of these newspapers whose comments are coloured by their chosen political affiliations. Because of this polarisation the researchers conclude by noting that public opinion on war veterans as portrayed by readers' online commentaries is also highly polarised and varied such that it is hard to determine or assert that there is one pattern of thought emerging in Zimbabwe concerning this group of people. This also justifies the view that media texts are polysemic to their audiences as these audiences bring with them past experiences and socialisations that range from religious, political to cultural.

\section{REFERENCES}

[1]. Alejandro,J (2010) Journalism in the age of social media ,Oxford: University of Oxford.

[2]. Allan,S and Thorsen E, ( 2009 ) Citizen Journalism: Global Perspectives,Peter Lang,NewYork

[3]. Almgren, S.M. and Olsson, T. (2015) “ 'Let's Get them Involved'...to Some Extent: AnalyzingOnline News Participation," Social Media and Society, 2015: 1-11.

[4]. Barret, C and Newbold, H (1995), Media Communication,New York:Palgrave Macmillian.

[5]. Bhattaracharrya,D.K (2003) Research Methodology, New Delhli,Excel books.

[6]. Bowman, S and Willis, C. (2003) "We media: How Audiences are shaping the future of News and Information :at www.american press.

[7]. Charles, A. (2012). Interactivity: new media, politics and society, Oxford: Peter LangUSA, Washington, DC. Chung ,D.S. and Yoo,Y.C. (2008) Audience Motivation for Using Interactive Features :Distinguishing Use of Different Types of Interactive on an Online Newspaper,Mass Communication and Society , 11:4,375-397.

[8]. Corner ,L .(2013) Audience engagement and the role of arts talk in the era,New York ,Palgrave Macmilliam.

[9]. Cresswell, J. W., \& Plano Clark,V . L. (2011). Designing and conducting mixed method research (2nd ed.). Thousand Oaks, CA: Sage.

[10]. Dahleberg,L (2001) The Internet Democratic Discourse :Exploring the prospects of Online Deliberate Forums Extenting the Public Sphere Information ,Communication and Society 4 (4) :615-33. Danesi ,P. (2006), Writing and reporting news:A coaching method,Cengage Learning.

[11]. Denzin ,N.K and Lincoln,Y.S (2003) Introduction:The discipline and practice of qualitative research ,Thousand Oaks,CA:Sage.

[12]. Dooley ,H (2003),Research Methods 3rd Edition,New Delhli,Prentice Hall.

[13]. Fers.rankfort-Nachmias .C and D,Nachmias. (2008)Research Methods in the Social Sciences (7th ed). New York: Worth Publish.

[14]. Finberg ,H and Stone M,L (2002), Djigital Journalism Credibility study .Washington D.C ;Online News Association at http;//www.journalism, org/Programs/credibility-study pdf (accessed 4 Nov 2002).

[15]. Frazosi,L.(2007) Qualitative Methods in Research,London,Sage Publications.

[16]. Gatsi,E. (2011), The Politics of the Mass Media :A personal experience ,Harare,Roblaw Printers.

[17]. Gerhads ,J (2009) Is the internet a better public sphere ? Comparing Old and New Media in the US and Germany ,new media and society, 20 (10)1-13.

[18]. Gerring,R.(2011) Purposive Sampling in Research Guide,Thousand Oaks :Sage Publications. 
[19]. Ghauri, P.N. (2005) Research Methods in Business Studies .A practical Guide .London: Pearson Education.

[20]. Glimmer ,A.(2001) Deliberate democracy ,The,Public Sphere and the internet 27(1), Golding and Murdoch. (2005), Communication for Development ,London,Sage.

[21]. Green ,J. and Thorogood,N. (2004) Qualitative Methods for Health Research. London: Sage.

[22]. Gunther ,A C (1992) Biased Press or Biased Public? Attitude Toward Media Coverage of Social Groups ,the Public opinion Quartely, Vol $2,147-167$.

[23]. Habermus, J.(1989 [1962]) The Structural Transformation of the Public Sphere: An inquiry into a Category of Bourgeois Society.Cambridge :Polity Press.

[24]. Hall ,S (1973) Encoding and Decoding model in The Television Discourse.

[25]. Hall, S (1997) Representation: Cultural Representations and Signifying Practices, London, Sage Publications.

[26]. Hall,S (1997) Representation :Culture Representations and Signifying Practices ,London,Sage Publications.

[27]. Herman ,E,S and Chomsky,N .(1998), Manfacturing Consent :The Political Economy of the Mass Media,London:Vintage.

[28]. Hjarvard, S,( 2000). News in a global culture. Gothenburg: Nordicom.

[29]. Ihlaebek ,K.A.and Krumsvik ,H.A.(2015) "Editorial Power and Publication Participation in onlineNewspapers",Journalism,Vol.16 (4) 470-487.

[30]. Ihlebaek, K.A. and Krumsvik, H.A. (2015) "Editorial Power and Public Participation in onlineNewspapers," Journalism, Vol. 16(4) 470-487.

[31]. Ito B .(2007) Introduction ;Networked Publics ,London,MIT Press.

[32]. Jenkins,H. (2006).Convergence culture :Where old and new collide.New York :New York University Press.

[33]. Johnson,T J , and Kaye B.K.Kaye (2003), Democracy’s Rebirth or Demise The influence of the Internet on Political Attitudes pg 209,NewYork ;Peter Lang.

[34]. Jorgensen,M and Phillips ,L. (2002) Discourse analysis as theory and method ,New Delhli:Sage Publications.

[35]. Jürgen Habermas, (1989). The structural transformation of the public sphere. Cambridge: Polity Press.

[36]. Kajuru ,Y, (2011) Audience Reception of media coverage and management of 2011 election in Kaduna State:Master of Arts in Development Communication Thesis.

[37]. Kammer ,A .(2003) “ Audience Participation in the Production of online news ,towards aTypology ,Nordicom Review 34 Special Issue ,113-126.

[38]. Kotler ,P. (1990) .Principles of Marketing,London,Sage.

[39]. Kumar ,R (2011) Research Methodology .A step -by - step guide for beginners .London :Sage.

[40]. Lewis -Beck,M.S ; A, Bryman \&T.F ,Liao .(2004) The Sage Encyclopedia of Social Science Research Methods .Online Publication.

[41]. Mararike ,D. (1973) The Media and Operations,Harare,Jongwe Printers.

[42]. Matacinskaite,J. (2011) The Internet as a "Public Sphere": The New York Times websites casestudy:Faculty of Communication ,Vilnius University ,Phd research paper.

[43]. Mhanda,W (2011) The role of war veteranism Zimbabwe Political and Economic Processes,Solidarity Peace Trust.

[44]. Mutsvairo ,S.(2013) Media perspectives in the African States,Harare,Jongwe Printers.

[45]. Neuman ,W.L .(2000) Social Research Method-Qualitative and Quantitative Approaches.Allan \&Bacon Publications.

[46]. Papacharissi ,Z,(2010) The Virtual Sphere 2.0 :The Internet ,the, Public Sphere and Beyond. Pornitakpan ,C .(2007) "The Pervasiveness of source credibility :A critical review of five decades Evidence Journal of Applied Psychology,(24) 243-281.

[47]. Purcell ,K (2010) Understanding the Participatory News Consumer : How Internet and cell phone users have turned news into social experience :Pew Research Center.

[48]. Rao ,N H and Rvi B.K (2015) Audience Perception of the credibility of Local News and Research Publications Vol 5.

[49]. Robson,M.(2004) Transforming Qualitative data ,description,analysis and interpretation, Thousand Oaks ,CA:Sage.

[50]. Schudson,J.(2003), Making News:A Study in the construction of reality,NewYork:Free.

[51]. Shannon,P. (2005) New Research Methods ,Oxford,Oxford University Press.

[52]. Shaqsi,A. (2013). Readership and Reader 's perception of Omani newspaper ,Global Media Journal Spring.

[53]. USA: Oxford University Press. 
[54]. Van Dijck, Jose. (2013).The cultureof connectivity: A critical history ofsocial media Van Dijk ,T.A.(2001) Critical DiscourseAnalysis in D.Schiffin,D,Tannen and H.Hamilton (eds) The Handbook of Discourse Analysis .Oxford :Blackwell.

[55]. Yin ,R.(2004) Qualitative data:An introduction to coding and analysis ,New York:New York University Press.

[56]. Zassoursky,N. (1997) Re-enforcement of the Media,New York,New York University Press. 